$\xi=$

\title{
Information Behavior of Managers (IBM) and Strategic Infor- mation Use (SIU) in Malaysian Industries
}

\author{
*Norhayati Hussin, Adnan Jamaludin \\ ${ }^{I}$ Faculty of Information Management, Uiniversiti Teknologi MARA, Shah Alam, Selangor, Malaysia. \\ *Corresponding author: *Norhayati Hussin: Faculty of Information Management, Uiniversiti Teknologi MARA, Shah Alam, Selangor, \\ Malaysia. \\ E-mail:yatihussin@gmail.com,adnanj@salam.uitm.edu.my
}

\begin{abstract}
This research examines the Information Behavior of Managers (IBM) and Strategic Information Use (SIU) in Malaysian industries. A total of 491 were involved in the study and results indicated that the IBM significantly influenced the strategic use of information in Malaysian industries. The results also showed that there were differences of IBM among industries in Malaysia. The findings of this study create awareness to the Malaysian industries on the importance of IBM. This study is perhaps one of the first to address IBM in the context of Malaysian industries.
\end{abstract}

Keywords: Strategic information, strategic information use, banking, Information Management

\section{Introduction}

The use of strategic information is relying on information behavior of the person in the organization. Managers are person who play a major role in organization to use the information for decision making. Information Behavior (IB) is the term that conveys how the person approaches and handles information during the life-cycle of information such as searching, using, sharing, hoarding, etc [1-2]. Moreover, Marchand, Kettinger and Rollins [3] elaborate that IB is the activity to inspire and support behavior in its people for effective use of information in organization. Effective information management requires a business to encourage proactive information behaviors and values among employees about using and sharing what they know with others, develop informationprocessing practices linked to business strategies and external market realities, and invest in Information Technology (IT) for management and innovation support, not just for running process and operations.

\section{Purpose of the study}

a) To examine the relationship of Information Behaviour of Managers (IBM) with Strategic Information Use (SIU) in Malaysian business environment.

b) To investigate is there a difference in Information Behavior of Managers (IBM) between industries in Malaysia.

\section{Research Questions}

Question 1: In the context of Malaysian business environment, to what extent does Information Behavior of Managers (IBM) relate to Strategic Information Use (SIU)?
Question 2: Is there a difference in the level of Information Behavior of Managers (IBM) between industries in Malaysia

\section{Literature Review}

\section{Strategic Information Use (SIU)}

The organization must fully utilize the valuable information pertaining to their business. It is also to consider some important information that has a strategic value [4-7]. The Strategic Information Use (SIU) has become popular among researcher since decades ago. Many researchers highlighted the importance of the Strategic Information Use (SIU) among managers in the field of their study such as real estate industry [8], financial industry [9-10], construction [11-12], education [13] and business [14].

Based on a study by Karim and Hussein [14], they found the managers in Malaysian business organization may not see information as highly diverse. Managers should provide effective information use in order to assist them to make good decision. In addition, the researchers suggest that managers must effectively use information strategically to ensure better position in the industry. Foss and Rodgers [9] have done a quantitative study among managers in global banking. This study examines whether the use of useful information enhances the managers' function related to unit in the organization. Senior line managers in a major global bank participated in the study was positively influenced by the strategic use of information related to their information processing. The assessments of the corporate audit information make clear decision making and increase level of productivity which would give direction to the success of the business.

From the discussion above, there is a gap between advanced and developing countries in terms of Strategic Information Use (SIU) among managers in business environment. Therefore, this study will refer to most of the literature from other countries to map with the current condition of Malaysian business environment. Business environment is very wide and competitive. The 
organization must be competitive in every level of the competition; competition within market, competition within industry and competition between organizations. To ensure that the organizations sustain the competition, they must be equipped with the business strategic weapon which is strategic information. Business organization must be able to strategically use information to compete in every level of competition. Strategic Information Use (SIU) about market, industry and organization are the strategic weapon $[7,15]$ and used by strategic level of management to formulate a plan, strategy and direction of the organization [15-18].

Therefore, this study defined the Strategic Information Use (SIU) is the utilization of information related to market, industry and organization by the industries to achieve the competitive advantage.

\section{Information Behaviour of Managers (IBM)}

Marchand et al., [3] identify six additional behaviors and value dimensions from the literature that have direct and indirect impacts on creating Strategic Information Use (SIU) among managers in organization. There are six information behaviors and values identified by Marchand et al. [3] to characterize the use of strategic information culture of the managers of an organization, such as information integrity, formality, control, sharing, transparency, and pro-activeness.

Information Integrity; Information security is accountable for information integrity. In that case, information integrity requires system integrity and data integrity equally [16]. Information integrity is defined as the use of information in a trustful and principled manner at the individual and organizational levels.

Information Formality; The next information behaviour concerns the relationship between formal and informal information use in an organization. Researchers found that both forms of communication and information use are necessary in organizations [3]. Information formality means that business organizations will push to establish formal processes and information flows to achieve predictable business results, to assure appropriate controls are in place, and to deliver products and services in a consistent manner [3]. Organizations should seek to supplement formal information for decision making using formal contacts and communications with people inside and outside the organization to check the reliability of formal information, or to supplement the formal information available, if necessary [3].

Information Control; The term 'control information' or 'information control' may be new, but the concept itself is not eccentric or strange. Many other theories over the years have articulated similar ideas. Since the year 1950 until now, there have been many papers published. Among them are Raymond (1950) [19], Rapoport (1956) [20], MacKay (1968, 1961) [21] [22], Weiss [23], Marchand et al., [3], Chen, Li, Zhou, Xiong, and An [24], Kroll and Proeller [25] as well as Filaretov, Yukhimets, and Mursalimov [26]. Information control is the extent to which information about performance is continuously presented to people to manage and monitor their performance. Managers use information to monitor and control operational activities and decisions to achieve intended strategy and improve business performance. Chen, Li, Zhou, Xiong, and An [24] state that there must be a control for information poor. It is difficult if the information system is poor. It could not deliver and process good information and it is impossible to solve a problem with it. In organization, there must be having an appropriate mechanism to control information so that it can be strategically utilize to help the organization for strategy formulation.

Information Transparency; the first obvious step is to denote exactly what is meant by 'transparency'. Transparency is associated with four characteristics. First, transparency means being candid with one's thoughts free from bias and accepting of the views of others. Second, transparency implies basic fairness a person will be honest, impartial, and fair in dealing with decisions and situations that arise. Third, transparency, like sharing, requires trust between people a sense of confidence that another person will not use your thoughts or information against you. Finally, transparency requires 'openness' to other people's thoughts and concerns even when the 'news' is negative or not good [3]. This suggests that high levels of personal and organizational integrity are required for being transparent about 'bad news' or surprises inside an organization [3].

Information Sharing; Information sharing is the willingness to provide others with information in an appropriate and collaborative fashion. This behaviour is well recognized by senior managers, particularly as it relates to internal information sharing. Information sharing is the degree of access to and sharing of important supply chain information between an organization and its supply chain partners [27]. Within organizations, information sharing has been emphasized as an important driver of organizational performance (Yang and Maxwell, 2011) [28]. Augmented information sharing can lead to improved organizational efficiency, learning, innovation, flexibility, and understanding of organizational goals (Constant et al., 1994 [29]; Hatala \& Lutta, 2009 [30]). Jarvenpaa and Staples (2000) [31] suggest information sharing embeds the concept of volition that differentiates information sharing from involuntary information reporting. We understand information sharing as a voluntary act of making information available to others (Jarvenpaa \& Staples, 2000) [31]. Effective information sharing relies upon an organization's ability to employ an IT infrastructure in the vertical and horizontal distribution of information across the organization (Davis \& Golicic, 2010) [32].

Pro-activeness; proactively refers to the ability to take initiatives, make conscious decisions, and take positive actions to achieve chosen goals. There are various kinds of proactive behaviours in teamwork. One of these, helping behaviour, is of particular interest in the literature (Edwars et al., 2014) [33]. In the multi-agent system (MAS) field, helping behaviour can be illustrated in several existing formal frameworks. For instance, from the viewpoint of the theory of joint intentions [34] helping behaviour occurs whenever a team member helps another with his/her responsibilities in order to achieve the goals to which they are committed. Proactive information delivery, by which mean providing relevant information without being asked [35]. Proactive information delivery offers an alternative, as it shifts the burden of updating information from the information consumer to the information provider, who typically has direct knowledge about any changes.

\section{Relationship between Information Behaviour of Managers (IBM) and Strategic Information Use (SIU)}

The effectiveness of Strategic Information Use (SIU) is relying on Information Behaviour (IB) of the person in organization. Information behaviour (IB) is the term that conveys how the person approach and handle information during the life-cycle of information such as searching, using, sharing, hoarding, etc. [1-2]. Marchand, Kettinger, and Rollins [3] elaborate IB as the activity to instil and promote behaviour and value in its people for effective use of information in organization. Information behaviour (IB) relates to the totality of human behaviour in relation to sources and channels of information, including both active and passive information-seeking, and information use [36]. Marchand et al., [3] demonstrate in their empirical study that organizations should do more than excel at investing in and deploying Information Management (IM) and with getting their people to embrace the right behaviour and values for working with information.

\section{Methodology}

This study proceeds in the following three stages:

Stage 1: A review of the literature; The literatures that address IM including related concepts such as Information management, Information technology, and information systems are reviewed. Meanwhile, to review commences seeking definition to IBM, 
related concepts are information behavior and information seeking behavior were used interchangeably throughout the study.

Stage 2: Collection data technique; The questionnaire was prepared in English as on approach to enhancing the prospect of a response. The questionnaires were distributed among 600 senior managers of the manufacturing and banking industries.

Stage 3: Data Analysis; All the data analyzed by the latest version of SPSS software and Smart PLS 2.0.

Strategic Information Use (SIU) for strategy formulation in Malaysia Business Organizations.

\section{Findings}

There were 491 questionnaires returned from banking and manufacturing industries. The following are the findings:

Table 1. Mean and standard deviation each items of SIU

\begin{tabular}{|c|c|c|c|c|}
\hline No & (SIU) & $n$ & Mean & Std. Dev \\
\hline 1 & New competitors of an organization & 491 & 5.7597 & 1.05138 \\
\hline 2 & Quality and quantity of the product and services of an organization & 491 & 5.7312 & 1.1871 \\
\hline 3 & Customer of an organization & 491 & 5.7251 & 1.14632 \\
\hline 4 & Government regulation that work aid an organization & 491 & 5.7006 & 1.03706 \\
\hline 5 & The employee of an organization & 491 & 5.6884 & 1.08545 \\
\hline 6 & Technology own by an organization & 491 & 5.6497 & 1.05148 \\
\hline 7 & Government policy towards industry & 491 & 5.6191 & 1.00181 \\
\hline 8 & Operation of an organization & 491 & 5.6049 & 1.01151 \\
\hline 9 & Management structure of an organization & 491 & 5.5642 & 1.05049 \\
\hline 10 & Growth rate of the industry & 491 & 5.5458 & 0.87798 \\
\hline 11 & Changing demographic that might exist an organization in increasing clients/customer base & 491 & 5.5255 & 1.05601 \\
\hline 12 & Information about finance & 491 & 5.5071 & 1.08112 \\
\hline 13 & New laws of the country & 491 & 5.5031 & 1.26228 \\
\hline 14 & Existing or potential products offered in the industry & 491 & 5.4807 & 1.01072 \\
\hline 16 & Consumer's behaviour in the industry & 491 & 5.4623 & 1.11763 \\
\hline 17 & Entry deterring price in the industry & 491 & 5.4053 & 0.94582 \\
\hline 18 & Credit availability & 491 & 5.4012 & 1.06901 \\
\hline 19 & Inflation rates & 491 & 5.3971 & 1.04545 \\
\hline 20 & Diverse strategize of others in the industry & 491 & 5.3523 & 1.14468 \\
\hline 21 & Industry usually requisite fight for market share & 491 & 5.3503 & 1.17954 \\
\hline 22 & Interest Rate & 491 & 5.2729 & 1.14235 \\
\hline
\end{tabular}

\section{Level of Strategic Information Use (SIU) of Managers}

\begin{tabular}{|l|c|}
\hline Mean & 5.4565 \\
\hline Std. Deviation & .77816 \\
\hline Minimum & 3.00 \\
\hline Maximum & 7.00 \\
\hline
\end{tabular}

Table 2. Level of SIU of managers
Table 2 above displays the descriptive statistics for level of Strategic Information Use (SIU) among organization in Malaysian industries. Based on the above-mentioned scale, the level of Strategic Information Use (SIU) in Malaysian industries is considered high with mean at 5.456 .

\section{Information Behaviour of Managers (IBM) in Malaysian Industries}

Table 3. Mean and standard deviation each items of IBM

\begin{tabular}{|c|c|c|c|c|}
\hline \multicolumn{2}{|r|}{ Information Behavior of Managers (IBM) } & \multirow{2}{*}{$\begin{array}{c}n \\
491 \\
\end{array}$} & \multirow{2}{*}{$\begin{array}{c}\text { Mean } \\
5.7373\end{array}$} & \multirow{2}{*}{$\begin{array}{c}\text { Std. Dev } \\
1.05667\end{array}$} \\
\hline 1) & Use information to respond quickly to changes in the competitive environment & & & \\
\hline 2) & Seek out information on changes and trends & 491 & 5.7352 & 1.11902 \\
\hline 3) & Use information to create or enhance products and services & 491 & 5.7047 & 1.17645 \\
\hline 4) & Business strategy is presented to employees and influences working behaviour & 491 & 5.4949 & 1.06401 \\
\hline 5) & Distribute information to justify decision already made & 491 & 5.2444 & 1.16818 \\
\hline 6) & Encourage openness & 491 & 5.2037 & 1.1461 \\
\hline
\end{tabular}

Based on the table above, managers in Malaysian industries are highly use information to respond quickly to changes in the competitive environment (5.7373), seek out information on changes and trends (5.7352), use information to create or enhance products and services (5.7047). It was also found that the managers in Malaysian industries present their business strategy to employees and influences working behaviour (5.4949), distribute information to justify decision already made (5.2444) and encourage openness (5.2037).

Table 4. Path coefficients, T-statistics, significant level for all hypothesised Paths

\begin{tabular}{|l|l|l|l|}
\hline $\begin{array}{l}\text { Dependent } \\
\text { Construct }\end{array}$ & $\begin{array}{l}\text { Path Coeffi- } \\
\text { cient }\end{array}$ & T Statistics & Hypotheses \\
\hline IBM -> SIU & 0.53 & 5.06 & Supported \\
\hline
\end{tabular}

To validate the proposed hypotheses and the structural model, the path coefficient value needs to be at least 0.1 to account for a certain impact within the model (Hair et al., 2011 [37]; Wetzels et al., 2009 [38]). Assessment of the path coefficient (Table 4.4) shows that there is a significant relationship between Information Behaviour of Managers (IBM) with Strategic Information Use (SIU) in Malaysian industries proposed hypotheses. This study has found that IBM has a significant relationship with SIU. This has proven by the hypothesis testing whereby the proposed hypothesis has a path coefficient value of more than 0.10 . The hypothesis was tested using Partial Least Squares (PLS) known as Smart PLS 2.0. From the Path Coefficient Value, it is possible to ascertain the strength of the relationship between latent variables and it was measured by looking at beta and $t$-value. The value of $\beta$ should exceed 0.10 and the t-value must be exceeding 1.96. Therefore, this study has found the hypothesis below to be accepted, the $\beta$ is 0.53 and $t$-value is 5.06 . 


\section{Concluded Remarks}

This study has attempted to reduce the gap in the literature on SIU in Malaysian industries. The study was undertaken specifically to shed more light on the Information Behavior of Managers (IBM) of organizations influencing SIU. It is a valuable contribution to the study of SIU in Malaysian industries, yielding important information for Information Management researchers, and local business practitioners. The study started by reviewing the literature, which produced a list of the information that support IBM and SIU as well as identified some gaps in this area, including the lack of research on the subject in developing countries compared to developed countries and in the Malaysian business sector. This study makes several contributions to the literature on SIU and IBM that influence the success of Malaysian industries. This study makes a contribution to knowledge by bringing to light the ubiquity of Information Management in Malaysian industries. The findings and recommendations in this paper could serve as guidelines to practitioners in the field of information management.

\section{Acknowledgement}

This research was supported by Lestari grant (600-IRMI/MYRA 5/3/LESTARI (0041/2016) from the Universiti Teknologi MARA, Shah Alam, Malaysia.

\section{References}

[1] Davenport, T. H. (1993). Process innovation: reengineering work through information technology. Boston: Harvard Business School Press.

[2] MacDonald, J., Bath, P., \& Booth, A. (2011). Information overload and information poverty: challenges for healthcare services managers? Journal of Documentation, 67(2), 238-263. doi:doi:10.1108/00220411111109458

[3] Marchand, D., Kettinger, W., and Rollins, J. (2001). Information orientation: the link ford University Press.

[4] Szewczak, E. J. (1988). Exploratory Results of a Factor Analysis of Strategic Information: Implications for Strategic Systems Planning Journal of Management Information Systems, 5(2), 83-97. http://doi.org/10.2307/40397886

[5] Hemmatfar, M., Salehi, M., \& Bayat, M. (2010). Competitive Advantages and Strategic Information Systems. International Journal of Business and $\quad$ Management, 5(7), 158-170. http://doi.org/www.ccsenet.org/ijbm

[6] Buchanan, S., \& Gibb, F. (1998). The information audit: An integrated strategic approach. International Journal of Information Management, 18(I), 29-47. http://doi.org/10.1016/S02684012(97)00038-8

[7] Frazier, G. L., Maltz, E., Antia, K. D., \& Rindfleisch, A. (2009) Distributor Sharing of Strategic Information with Suppliers. Journal of Marketing, 73(4), 31-43. http://doi.org/10.1509/jmkg.73.4.31

[8] Crowston, K., Sawyer, S., \& Wigand, R. (2001). Investigating the interplay between structure and information and communications technology in the real estate industry. Information Technology and People, 14(2), 163-183. http://doi.org/10.1108/09593840110695749

[9] Foss, K., \& Rodgers, W. (2011). Enhancing Information Usefulness by Line Managers' Involvement in Cross-Unit Activities. Organization Studies, 32(5), 683-703. http://doi.org/10.1177/0170840611407017

[10] Gu, Z., Guo, X., \& Jian, L. (2013). An Empirical Study on the Factors Affecting Carbon Accounting Information Disclosure of Chinese Listed Organizations. International Conference on Low-Carbon Transportation and Logistics, and Green Buildings., 995-1000. http://doi.org/10.1007/978-3-642-34651-4

[11] Mäki, T., \& Kerosuo, H. (2014). Site managers' uses of building information modeling on construction sites. In Proceedings 29th
Annual Association of Researchers in Construction Management Conference, ARCOM 2013 (pp. 611-621). Retrieved from http://www.scopus.com/inward/record.url?eid=2-s2.084911431085andpartnerID=tZOtx3y1

[12] Chung, Y., \& Wang, W. (2004). The levels of information technology adoption, business network, and a strategic position model for evaluating supply chain integration. Journal of Electronic Commerce Research, 5, 85-98. Retrieved from http://www.csulb.edu/journals/jecr/issues/20042/Paper2.pdf

[13] Haeussler, C. (2011). Information-sharing in academia and the industry: A comparative study. Research Policy, 40(1), 105122. http://doi.org/10.1016/j.respol.2010.08.007

[14] Karim, N. S. A., \& Hussein, R. (2008). Managers' perception of information management and the role of information and knowledge managers: The Malaysian perspectives. International Journal of Information Management, 28(2), 114-127. http://doi.org/10.1016/j.ijinfomgt.2007.08.003

[15] King, W. R. (1983). Information as a Strategic Resource. MIS Quarterly, 7, iii-iv. Retrieved from http://search.ebscohost.com/login.aspx?direct=trueanddb=buhandA $\mathrm{N}=28044328$ andsite $=$ ehost-live

[16] Flowerday, S., \& von Solms, R. (2005). Real-time information integrityand\#xa0;=and\#xa0;system integrityand\#xa0;+and\#xa0;data integrityand\#xa0;+and\#xa0; continuous assurances. Computers and Security, 24(8), 604-613 doi:http://dx.doi.org/10.1016/j.cose.2005.08.004

[17] Frishammar, J. (2003). Information use in strategic decision making. Management Decision, 41(4), 318-326. http://doi.org/10.1108/00251740310468090

[18] Buhalis, D. (1998). Strategic use of Information Technologies in the tourism industry. Tourism Management, 19(5), 409-421.

[19] Raymond (1950) - missing

[20] Rapoport (1956) - missing

[21] MacKay (1968) -missing

[22] MacKay (1961)-missing

[23] Weiss, J. W., \& Anderson, D. (2004). Aligning technology and business strategy: issues and frameworks, a field study of 15 organizations. 37th Annual Hawaii International Conference on System Sciences, 2004. Proceedings of the, 8(C), $10 \mathrm{pp}$ http://doi.org/10.1109/HICSS.2004.1265511]

[24] Chen, M. Y., Li, Z., Zhou, L., Xiong, H.,\& An, X. (2004). SCGM-model and grey control of "poor" information systems. Kybernetes, 33(2), 231-237. doi:doi:10.1108/03684920410514157

[25] Kroll, A., \& Proeller, I. (2013). Controlling the control system: performance information in the German childcare administration. International Journal of Public Sector Management, 26(1), 74-85. doi:doi:10.1108/09513551311293435

[26] Filaretov, V., Yukhimets, D., \& Mursalimov, E. (2015). The Universal Onboard Information-control System for Mobile Robots. $\begin{array}{lll}\text { Procedia } & \text { Engineering, } & \text { 737-745. }\end{array}$ doi:http://dx.doi.org/10.1016/j.proeng.2015.01.427

[27] Chengalur-Smith, I., Duchessi, P., \& Gil-Garcia, J. R. (2012). Information sharing and business systems leveraging in supply chains: An empirical investigation of one webbased application. Information and Management, 49(1), 58-67. http://doi.org/10.1016/j.im.2011.12.001

[28] Yang and Maxwell, 2011) -missing

[29] Constant et al., 1994 -missing

[30] Hatala \& Lutta, 2009 -missing

[31] Jarvenpaa and Staples (2000) -missing

[32] Davis \& Golicic, 2010) - missing

[33] Edwars et al., 2014) -missing

[34] Jamali, H., \& Nicholas, D. (2008). Information-seeking behaviour of physicists and astronomers. Aslib Proceedings, 60(5), 444-462.

[35] Fan, X., Yen, J., \& Volz, R. A. (2005). A theoretical framework on proactive information exchange in agent teamwork. Artificial Intelligence, 169(1), doi:http://dx.doi.org/10.1016/j.artint.2005.06.005

23-97.

36] Timmers, C. F., and Glas, C. a. W. (2010). Developing scales for information-seeking behaviour. Journal of Documentation, 66, 4669. http://doi.org/10.1108/00220411011016362

[37] Hair et al., 2011 -missing

[38] Wetzels et al., 2009 [38]- missing 